\title{
The first report of the main vector of visceral leishmaniasis in America, Lutzomyia longipalpis (Lutz \& Neiva) (Diptera: Psychodidae: Phlebotominae), in the state of Rio Grande do Sul, Brazil
}

\author{
Getúlio Dornelles Souza', Edmilson dos Santos², José Dilermando Andrade Filho³/+ \\ 'Seção de Reservatórios e Vetores, Divisão de Biologia Médica, Instituto de Pesquisas Biológicas, Laboratório Central de Saúde Pública \\ do Rio Grande do Sul, Fundação Estadual de Produção e Pesquisa em Saúde ²Divisão de Vigilância Ambiental em Saúde, Centro Estadual \\ de Vigilância em Saúde, Secretaria Estadual de Saúde do Rio Grande do Sul, Centro Estadual de Vigilância em Saúde, Porto Alegre, RS, \\ Brasil ${ }^{3}$ Centro de Referência Nacional e Internacional para Flebotomíneos, Laboratório de Leishmanioses, Instituto René Rachou-Fiocruz, \\ Av. Augusto de Lima 1715, 30190-002 Belo Horizonte, MG, Brasil
}

Visceral leishmaniasis (VL) is a widespread zoonosis in Brazil and, up to now, there has been no record of the main vector of its agent, Lutzomyia longipalpis, in the Southern Region. Due to the diagnosis of VL in a dog in October 2008 in the city of São Borja, in the southernmost Brazilian state of Rio Grande do Sul, a collection of phlebotomines was undertaken to detect the presence of the vector Lu. longipalpis. The captures were carried out with CDC light traps on three consecutive nights in 2008. A total of 39 specimens of Lu. longipalpis were captured, thereby increasing the knowledge of the geographical distribution of this important vector.

Key words: Lutzomyia longipalpis - sand fly - Rio Grande do Sul - leishmaniasis

Visceral leishmaniasis (VL) is a widespread zoonosis in Brazil with high lethality among untreated individuals and malnourished children, as well as among the immunodeficient (Rabello et al. 2003). Lutzomyia longipalpis (Lutz \& Neiva), the main vector of its agent, although presenting a wide distribution in Brazilian territory, has not so far been found in the municipalities of the Southern Region (MS 2006) and the furthest south this species had been recorded in Brazil is in state of São Paulo (Aguiar \& Medeiros 2003).

VL has also not been registered in the Southern Region, with the exceptions being two human cases reported in the state of Paraná during the 70s (Cat et al. 1973, 1974, Ayala et al. 1980) and five dogs with canine visceral leishmaniasis (CVL) in Santa Maria city, state of Rio Grande do Sul (RS) (Pocai et al. 1998). After this report in RS, Marcondes et al. (2003) carried out a survey of CVL in this municipality, examining 204 dogs that presented negative results for the infection. This fact led these authors to question the positive results presented in the previous report.

In Argentina, Lu. longipalpis was collected in Misiones province in 1951 and 2000 in the municipal districts of Candelaria and Corpus, respectively, although with no record of VL cases (Salomón et al. 2008). In 2004, the species was captured in Clorinda and Puerto Pilcomayo, Formosa province (Salomón \& Orellano 2005) and, in 2006, it was collected in Posadas (capital of MI) and Candelaria (Salomón et al. 2008). Furthermore,

Financial support: Secretaria de Vigilância em Saúde, Ministério da Saúde +Corresponding author: jandrade@cpqrr.fiocruz.br

Received 21 May 2009

Accepted 4 September 2009 according to these last authors, one human and several CVL cases were confirmed in the same year in Posadas and nine other human cases were diagnosed in 2007.

In October 2008, CVL was diagnosed in a dog living in a residence situated in the centre of São Borja city in the northwest region of RS. The Uruguay River marks the boundary between the São Borja municipality and that of São Tomé in Corrientes province, Argentina, as well as between other municipal districts of RS and the Argentinean provinces of Corrientes and Misiones.

Due to the case of CVL registered in São Borja, the above-mentioned history of the disease in humans in MI, the reports from the authorities in Corrientes of the disease in dogs there and the intense flow of people and trade between the two countries over the international bridge São Borja - Santo Tomé, a collection of phlebotomines was carried out in the centre of the city of São Borja, aiming to detect the presence of the vector $\mathrm{Lu}$. longipalpis and investigate the autochthony of the CVL case.

The municipal district of São Borja has a total area of $3,616 \mathrm{~km}^{2}$ and a population of 61,834 inhabitants, with the urban area occupying $71 \mathrm{~km}^{2}$ and having a resident population of about 58,000 people. The climate is subtropical humid and the maximum altitude is $123 \mathrm{~m}$ asl, with that of the town being $96 \mathrm{~m}$. The captures in the city were undertaken by the team from the Vigilância Ambiental of the $10^{\mathrm{a}}$ Coordenadoria Regional de Saúde, in November and December 2008, on three consecutive nights of each month for $12 \mathrm{~h}$ per night (18-6 h). In November, three CDC light traps were installed, one in the domicile where the infected dog lived and the others in two adjacent residences with VL symptomatic dogs. In December, five other residences in which dogs with symptoms compatible with CVL had died were sampled. These residences were located within a radius of $700 \mathrm{~m}$ from that in which the dog diagnosed as having LV had died in October 2008. 
The insects were prepared, mounted and identified in accordance with Galati (2003) at the Laboratório Central de Saúde Pública do Rio Grande do Sul (LACEN/ RS). Afterwards, the identification was confirmed in the Centro de Referência Nacional e Internacional para Flebotomíneos of the Laboratório de Leishmanioses, Instituto de Pesquisas René Rachou-Fiocruz, Minas Gerais.

In November, only three male phlebotomines were collected and identified as belonging to the species $L u$. longipalpis, two of them being from the house where the dog diagnosed as having CVL had lived. These specimens were deposited in the scientific collection of the Seção de Reservatórios e Vetores of LACEN/RS (lots 692, 693 and 694). In December, 36 specimens of $L u$. longipalpis were captured: 30 males and six females.

One of the residences sampled, located near the central square of the town, in the woods, with fruit trees and having a kennel with two dogs, stood out by virtue of the number of phlebotomines collected (28), with 25 in just one night.

With this finding of $L u$. longipalpis, a species not hitherto reported in the southern region of the country, in the urban area of the municipal district, we believe the municipal, state and national authorities, as well as the local inhabitants should be alerted to the serious public health problem thus posed and recommend the adoption of the measures proposed in the manual for surveillance and control of VL (MS 2006).

Previously, 23 species of phlebotomines had been reported in RS, among which Nyssomyia neivai (Pinto), a species involved in the transmission of the etiologic agent of cutaneous leishmaniasis in various regions of Brazil and Argentina (Cordoba-Lanús et al. 2006, Andrade Filho et al. 2007), was of special relevance. The present record increases our knowledge of the geographical distribution of $L$. longipalpis and of the expansion of VL infection as confirmed by the competent agencies.

\section{ACKNOWLEDGMENTS}

To Mr. João Medeiros, of the Vigilância Ambiental of the $10^{a}$ Coordenadoria Regional de Saúde, Municipal District of Alegrete, for carrying out the collections, and to the veterinary surgeon Janaína Leivas, of the Vigilância Sanitária of the municipal district of São Borja, for her information and support in the field activities.

\section{REFERENCES}

Aguiar GM, Medeiros WM 2003. Distribuição regional e habitats das espécies de flebotomíneos do Brasil. In EF Rangel, R Lainson (eds.), Flebotomíneos do Brasil, Fiocruz, Rio de Janeiro, p. 207-255.

Andrade Filho JD, Galati EAB, Falcão AL 2007. Nyssomyia intermedia (Lutz \& Neiva, 1912) and Nyssomyia neivai (Pinto, 1926) (Diptera: Psychodidae: Phlebotominae) geographical distribution and epidemiological importance. Mem Inst Oswaldo Cruz 102: 481-487.

Ayala MAR, Bergoxc PM, Anunciação EM 1980. Calazar (primeiro caso autóctone no sudeste do Paraná). J Bras Med 39: 88-89.

Cat I, Luz E, Borba AM, Cassilha A, Costa PB, Martins FL 1973/1974. Leishmaniose visceral autóctone no oeste paranaense. An Fac Med Univ Fed Paraná 16/17: 27-35.

Córdoba-Lanús EML, Valladares B, Salomón OD 2006. Natural infection of Lutzomyia neivai with Leishmania spp in Northwestern Argentina. Acta Trop 98: 1-5.

Galati EAB 2003. Classificação de Phlebotominae. In EF Rangel, R Lainson (eds.), Flebotomíneos do Brasil, Fiocruz, Rio de Janeiro, p. 23-51.

Marcondes CB, Pirmez C, Silva ES, Laurentino-Silva L, Steindel M, Santos AJ, Smaniotto H, Silva CFB, Schuck Neto VF, Donetto A 2003. Levantamento de leishmaniose visceral canina em cães de Santa Maria e municípios próximos, Estado do Rio Grande do Sul. Rev Soc Bras Med Trop 36: 499-501.

MS - Ministério da Saúde, Secretaria de Vigilância em Saúde, Departamento de Vigilância Epidemiológica 2006. Manual de vigilância e controle da leishmaniose visceral, MS, Brasília, 120 pp.

Pocai EA, Frozza L, Headley SA, Graça DL 1998. Leishmaniose visceral (calazar). Cinco casos em cães de Santa Maria, Rio Grande do Sul, Brasil. Cienc Rural 28: 501-505.

Rabello A, Orsini M, Disch 2003. Leishmania/HIV co-infection in Brazil: an appraisal. Ann Trop Med Parasitol 97: 17-28.

Salomón OD, Cíngara A, Nevot MC, Barberian G, Paulin P, Estevez JO, Riarte A, Estevez J 2008. First visceral leishmaniasis focus in Argentina. Mem Inst Oswaldo Cruz 103: 109-111.

Salomón OD, Orellano PW 2005. Lutzomyia longipalpis in Clorinda, Formosa province, an area of potencial visceral leishmaniasis transmission in Argentina. Mem Inst Oswaldo Cruz 100: 475-476. 